\title{
SOUTH AFRICAN NATIONAL DEFENCE FORCE (SANDF) DROPS CHARGES AGAINST HIJAB- WEARING OFFICER: CASE IN POINT SOUTH AFRICA
}

\begin{abstract}
Ashraf Booley ${ }^{1}$
ABSTRACT

Over the lastfew decades, a piece of fabric has become a powerful and divisive symbol worldwide. Since the tragic events of 9/11, this piece of fabric has become a topic of great debate, at local, national, regional and international level. ${ }^{2}$ The veil as worn by some Muslim women has assumed iconic proportions around the globe. To some it symbolizes piety to others, oppression. To some it is a rejection of Western morality to others, a rejection of modernity. To some, it is a religious statement supporting Islam as a way of living; to others, a political statement supporting violent Islamists. These disparate attributions exemplify the power of nonverbal communication and support the maxim that words and objects contain no inherent meaning; only people assigned meaning. This article discusses the status of religious rights and freedoms under the South African Constitution. One
\end{abstract}

Senior Lecturer, Department of Private Law, University of the Western Cape, South Africa, abooley@uwc.ac.za

2 On September 11 2001, an American Airlines Boeing crashed into the World Trade Center in New York. It is believed 19 militants associated with the Islamic extremist group Al Qaeda hijacked four airplanes and carried out suicide attacks against targets in the United States. See History, 'September 11 Attacks,' http:// www.history.com, accessed on 14 July 2020. There are many other theories which has come to light since that tragic event, however, those theories are beyond the scope of this article. 
aspect of this change is the change that has affected the various religions, cultures, and customs in South Africa. It is therefore, viewed by many as a constitution for the people of South Africa which includes a Bill of Rights. Historically speaking, for the very first time since colonialism, all religions were guaranteed the of religion. Furthermore, religions, cultures and languages are deep-rooted in the various constitutional provisions, namely, sections 9(3), 15(1) to (3), 30, 31, 185 and 234 respectively. These constitutional provisions are solidified by section 7 which obliges the state to respect, protect, promote and fulfil the provisions set forth in the Bill of Rights. The article concludes with an argument for the recognition of plurality of religions and religious legal systems in South Africa.

Keywords: religion, freedom, legal pluralism, belief, equality, culture

\section{INTRODUCTION}

In 2018, Major Fatima Isaacs, was charged in a military court for 'wilful defiance and failing to obey a lawful command' after a superior asked her to remove the headscarf when wearing her military uniform. ${ }^{3}$ The South African National Defence Force (SANDF) is being accused of practising double standards in connection with a Muslim (woman) army major (rank within the SANDF) who is facing dismissal for refusing to remove her headscarf. Major Fatima Isaacs, in turn, is accusing the SANDF of Islamophobia. Major Fatima Isaacs has been in the SANDF for ten years, working as a forensic technologist at 2 Military Hospital in Cape Town. She says she has always been allowed to wear her headscarf invisibly under her beret and it has never interfered with, or covered up, her military insignia. In July of 2019, the SANDF, the Muslim Judicial Council of South Africa (MJC) ${ }^{4}$ and Fatima Isaacs's legal team agreed on interim relief that allows for Muslim women serving in the SANDF to wear

3 eNCA, 'SANDF drops charges against hijab-wearing officer,' www.enca.com, accessed on 31 December 2020.

4 The Muslim Judicial Council (MJC) is a non-profit organisation or a faithbased organisation which was established in 1945. It is one of the oldest, most representative and most influential in South Africa enjoying local, national and international credibility. The MJC decides issues of marriage, divorce, maintenance, succession and other legal issues. A case in point is the halal certificate issued to various establishments, indicating to Muslims that it will be acceptable to eat at those establishments. See Muslim Judicial Council (SA), http://www.mjc.org.za, accessed on 14 July 2020. 
an under-scarf. The wearing of the headscarf in South Africa has not really been an issue until now.

This, brief note investigates whether the right to freedom of religion as enshrined in the Republic of South African Constitution 1996, especially the provisions of Chapter 2 Bill of Rights ${ }^{5}$ has been violated by the actions of the SANDF? In addition, this brief note looks at the interplay between religion and legal pluralism within a constitutional framework.

\section{SOUTH AFRICAN POPULATION}

South Africa is a country of many religions and cultures therefore one could argue that it is indeed a country of pluralities. South Africa has a population of about 51770560 million inhabitants made up of 79.2 percent black people, $8.9 \%$ percent white people, $8.9 \%$ coloured people ${ }^{6}, 2.5 \%$ Indians/Asians, and

The supremacy of the Constitution of the Republic of South Africa of 1996 is recognised in section 1(c) which forms part of the Founding Provisions and in section 2 which reads: "[t] his Constitution is the supreme law of the Republic; law or conduct inconsistent with it is invalid, and the obligations imposed by it must be fulfilled". Section 15 and in particular section 15(3) of the Constitution of the Republic of South Africa of 1996 which entrenches freedom of religion, belief and opinion.

6 The Muslim Judicial Council (MJC) is a non-profit organisation or a faithbased organisation which was established in 1945. It is one of the oldest, most representative and most influential in South Africa enjoying local, national and international credibility. The MJC decides issues of marriage, divorce, maintenance, succession and other legal issues. A case in point is the halal certificate issued to various establishments, indicating to Muslims that it will acceptable to eat at those establishments. See Muslim Judicial Council (SA), http:/www.mjc.org.za, accessed on 14 July 2020. Of note, there are similar organisations in the various provinces of South Africa. The term 'coloured' may be viewed as offensive, however, it is only used to denote the demographics of South Africa, and it is not meant to be discriminatory at all. The 'coloured' people of South Africa are considered as people of mixed lineage. They are descendants of slaves who were brought to the country from East and Central Africa, the indigenous Khoisan, who lived in the Cape at the time, indigenous African's and Whites. The majority speaks Afrikaans available at http://www.southafrica.info/about/people/popoulation.htm, accessed on 16 July 2020. 
$0.5 \%$ per cent 'other. ${ }^{7}$ The plurality of cultures within the different cultural groups is reflected in the fact of eleven official languages, which are reflected in the percentage of speakers of each language in comparison with the total population. ${ }^{8}$ In terms of religion, $79.8 \%$ of South Africans are followers of Christianity, $0.2 \%$ are followers of Jewish faith, $1.1 \%$ follow Islam, $1.3 \%$ follow the Hindu faith and $0.1 \%$ are Buddhist followers. ${ }^{9}$ In addition there a degree of uncertainty as to the number of followers in term of African traditional religions in South Africa. We can therefore conclude that South Africa does not only consist of a plurality of cultures, as is evident of the 11 official languages, but also a plurality of religions which all could legitimate their share of the new South Africa.

In light of the above, it has become necessary to examine ambit of pluralism, especially legal pluralism in South Africa. Legal pluralism refers to a system where the inhabitants of a country are allowed to decide for themselves the law applicable to them as long as it is not contra bonis mores (against the morals of society or the state) of the land.$^{10}$ A multicultural society has always been evident in South Africa history, although those laws of a multicultural society has not always been acknowledged fully and only to a certain extent. Although, legal effect has been afforded to certain institutions, for example the Muslim and Hindu sects of the population. ${ }^{11}$ The legal system that has been in operation for considerable period of time was that of time a Western legal system stemming from colonialism, apart from customary law which was officially recognised to a limited extent. ${ }^{12}$ Inferences from the above dictates that if people are governed by a system of uniform law, then an argument can be formulated that the concept of legal pluralism, is non-existent in South Africa.

According to Mofokeng, that the South African legal system is based on legal parallelism in contrast to legal pluralism. ${ }^{13}$ This is evident in South

7 http://www.southafrica.info/about/people/popoulation.htm, accessed on 16 July 2020.

8 Coertzen P., 'Constitution, Charter and Religions in South Africa,' African Human Rights Law Journal (2014): 127-142.

9 Coertzen P., 'Constitution, Charter and Religions in South Africa,' 127-142.

10 Rautenbach C. (ed.), Introduction to Legal Pluralism in South Africa, $5^{\text {th }}$ ed. (South Africa: LexisNexis, 2018), 5.

11 Rautenbach C. (ed.), Introduction to Legal Pluralism in South Africa, 5.

12 Rautenbach C. (ed.), Introduction to Legal Pluralism in South Africa, 5.

13 Mofokeng L., 'The Right to Freedom of Religion: An Apparently Misunderstood Aspect of Legal Diversity in South Africa,' Law Democracy and Development, vol. 11/2 (2007): 129-130. 
Africa, as only customary law is so far recognised alongside civil law, and as yet no other personal law system/s have been acknowledged. However, despite the above, South Africa has made strides in formulating a Muslim Marriages Bill since 1993, sadly it has reached a stalemate. ${ }^{14}$ The constitution is the supreme law in South Africa ${ }^{15}$ and, in guaranteeing freedom of religion and culture, obliges the state to enact legislation recognising marriages, or systems of religious, personal and family laws. What arises is, the question whether the constitutional provisions contained in the Bill of Rights creates a right to have communities personal or family legal system afforded such recognition. Therefore, in terms of the right of religious freedom, inference may be drawn from the above that religious freedom includes the recognition of the various groupings religious or personal family laws as adhered by those groups.

In this article we will be focussing on section 15 , the protection of the right to religious freedom, although there may be an overlapping of other rights as per the Bill of Rights. In light of the above, we could postulate that principles or concepts of religion and law are inter-woven that intervention with the one would lead to interference with the other. ${ }^{16}$ According to Rautenbach, there is an overwhelming opinion in favour that the constitution recognises a right not to acknowledge aspects of the various religious legal systems in South Africa. ${ }^{17}$ Therefore, the right to freedom of religion, read with the right to equality, does not create a right to such recognition. ${ }^{18}$ This means according to the above,

14 Rautenbach C., 'Some Comments on the Current (and Future) Status of Muslim Personal Law in South Africa,' Potchefstroom Electronic Law Journal, vol. 2 (2004): 1-34. The South African Law Reform Commission has been involved in the investigation of Muslim personal law since 1990. The first project committee that was appointed did not make much progress into the codification of Muslim personal law. The reason for the delay were not made clear. It could be argued that the finalization of the Constitution was perhaps one of the most important reasons and a divergence of opinions relating to contentious issues could be also be advanced. Sadly, the South African Law Reform Commission did not make public any of its findings for debate. South African Law Reform Commission Project 59 - Islamic Marriages and Related Matters (May 2000) as well as South African Law Reform Commission Project 106 - Islamic Marriages and Related Matters (July 2003). A comprehensive discussion relating to the Muslim Marriages Bill, is beyond the scope of this article.

15 Constitution of the Republic of South Africa 1996, section 2.

16 Bhattacharjee A., Muslim Law and the Constitution, $2^{\text {nd }}$ ed (Calcutta: Eastern Law House, 1994), 225.

17 Rautenbach C., 'Muslim Marriages in South Africa,' Griffin 's View on International and Comparative Law, vol. 7/1 (2006): 55-74.

18 Rautenbach C., 'Muslim Marriages in South Africa,' 55-74. 
that the constitution only sanctions recognition of certain aspects of religious legal systems by means of legislation and does not create a right to have those certain aspects recognised. ${ }^{19}$ This has become a fiercely contentious issue within a constitutional framework in South Africa, and continues so far. We will now focus on the constitutional provision of the right to religious freedom.

\section{CONSTITUTIONAL PROTECTION OF THE RIGHT TO RELIGIOUS FREEDOM}

In terms of section 15(1) of the South African constitution it states the following: "everyone has the right to freedom of conscience, religion, thought, belief and opinion". ${ }^{20}$ Mofokeng interprets section 15, that various communities or groupings adhering to distinctive cultural and religious traditions should be afforded legal protection for their particular adherents of customs as well as systems of personal laws, as long as those customs and personal legal systems do not contravene any of the constitutional provisions as contained in the constitution. ${ }^{21}$ We could argue that section 15(1), lays the foundation upon which the individual or communities are guaranteed this rights, upon which other rights could be built upon.

In terms of section 15(1) which guarantees the right of every person in South Africa to belief or an opinion, subsection 15(3) undoubtedly draws a discrepancy between freedom of belief, on the side, and the right to practice such religion of belief on the other. It is suggested that this section impacts the right of any person to adhere to his/her religion or practice. Section 15(3) (a) states the following: "This section does not prevent legislation recognising (i) marriages concluded under traditional, or a system of religious, personal or family law; or (ii) systems of personal and family law under tradition, or adhered to by persons professing a particular religion". ${ }^{22}$ Mofokeng suggests that section 15(3)(a) encompasses a negative right in opposition to positive right, arguing that there is no pressure on the part of the legislature to legally recognise religious practices and religious legal systems. ${ }^{23}$

\footnotetext{
19 Rautenbach C., 'Muslim Marriages in South Africa,' 55-74.

20 Constitution of the Republic of South Africa 1996, section 15.

21 Mofokeng L., 'The Right to Freedom of Religion: An Apparently Misunderstood Aspect of Legal Diversity in South Africa,' 129-130.

22 Constitution of the Republic of South Africa 1996, section 15(3)(a).

23 Mofokeng L., 'The Right to Freedom of Religion: An Apparently Misunderstood Aspect of Legal Diversity in South Africa,' 129-130.
} 
The result of such an argument suggest that the legislature has a choice as to whether to enact law (now or in the future) that will result in the recognition of religious legal systems, beliefs and practices. ${ }^{24}$ It is put forward that the constitutional provisions of protection relating to "freedom of conscience, religion, thought, belief and opinion" seems to only protect the religious belief, but does not recognise the observation of one's religion, in other words one's religious legal system. This section seems not to afford protection of the practice, referring to the conduct of the individual or communities which is normally correlated with a religious legal system. For example, one's belief and practice (conduct) cannot be alienated because belief leads to the practice based on one's belief. Another example, if the matter of Fatima Isaacs, if she belongs and practices a certain faith, then she has a constitutional right to belief and practice her religion without any form of discrimination and persecution. It is postulated that to wear a headscarf which fall in the ambit of culture and religious personal law of a person should be legally recognised, on the proviso, the practice does not violate any other constitutional provisions in the constitution.

\section{SECTION 15 OF THE POSSIBLE CONSTITUTION DEFECTS}

The issue at hand is one of contrast, between the practising of one's religion and the right of belief which emerges from personal or religious law. From an Islamic perspective, one of the primary sources that being the holy Quran. ${ }^{25}$ Evidence of the above is provided in the following ayat/s or verses, namely:

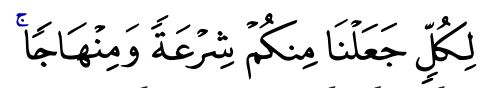

"To each among you, we have prescribed a clear law and a clear way." 26

(Surah al-Mā'idah, 5: 48)

\footnotetext{
24 Rautenbach C., 'Muslim Marriages in South Africa,' 55-74.

25 Warren C., 'Lifting the Veil: Women and Islamic Law,' Cordoza Journal of Law \& Gender, vol. 15/1 (2008): 33. The word Quran means reading or recitation and is the most authoritative guide for Muslims and the first source when interpreting the laws of Islam. The Quran, which consists of the verbatim words of Allah/God, was revealed to Prophet Mohammed [PBUH] over a period of more or less 23 years and contains 114 suras, or chapters, and 6235 ayat/s, or verses, of unequal length. Out of the total numbers of ayat/s or verses in the Quran, approximately 600 , or fewer than one tenth, provide legal rules or address legal questions.

26 Yusuf Ali A., The Holy Quran: Text, Translation and Commentary (Lahore: Ashraf Press, 1938), see Chapter Al-Ma'idah verse 48.
} 


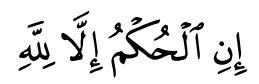

"The hukm (rule, injuction, and prescription) belongs to God Alone." 27

(Surah al-An'ām, 6: 57)

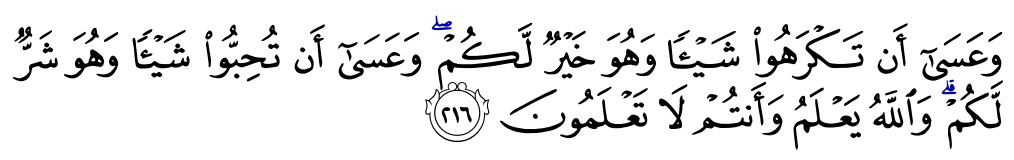

"And it may happen that you dislike a thing which is good for you and that you like a thing that is bad for you. Allah knows but you do not know." 28

(Surah al-Baqarah, 2: 216)

The extracted verses of the holy Quran suggest that according to Islam or/ and (perhaps other religions) that the powers of the lawmaker is God and God alone. The result is that religion or belief including the law associated with religion or belief are intertwined. As, a consequence, it may not always be accepted not to abide one's religious legal system in approval of secular law resulting as a person would be in violation of one's religion. For example, the headscarf as worn by women (in Islam men also wear a headscarf as well as in other religions $)^{29}$, she may decide to wear a headscarf as part of her religion and therefore it is acceptable, because her religion permits the wearing of a headscarf. If she decides, not to wear a headscarf she may feel that she is not fulfilling her religious obligations. In contrast, the right to freedom of religion and the practising of one's religion, is considered as futile, because such a right is limited only to the protection of 'belief' which cannot be separated from the practice of that belief.

The issue at hand is the following, is it possible in South Africa for a person to belong to a religious community, and to be guaranteed the protection of freedom of religion as enshrined in section 15 of the constitution in terms of religion and practice? Globally, most people consider themselves bound

27 Yusuf Ali A., The Holy Quran: Text, Translation and Commentary, Chapter alMa'idah verse 48. 6:57.

28 Yusuf Ali A., The Holy Quran: Text, Translation and Commentary, Chapter alMa'idah, verse 48. 2:216.

29 For example, men in the Jewish faith wear Orthodox Jewish men always cover their heads by wearing a skullcap known in Hebrew as a kippah or in Yiddish as a yarmulke. See BBC.com, http://www.bbc.co.uk, accessed on 20 December 2020. 
by their respective beliefs, for example, Muslim bound by the Quran, for the Jewish community the Torah, the Hindu community the Vedas and the Christian community the Bible and others. ${ }^{30}$ A common denominator is that in most of the dominant faiths, their respective religious systems are deemed divine by their individual followers, and as, a consequence their scriptures are deemed the supreme law of those respective dominant faiths. ${ }^{31}$ Inferences can therefore be put forward, in the dominant religions no exceptions (or perhaps a few) can be made in favour of secular law or any other law that contrast a person's religious law. ${ }^{32}$

Therefore, how does one interpret section 15 in a South African constitutional context? Mofokeng puts forward that the only way of interpreting section 15, read together with the its various sub-sections, ${ }^{33}$ guarantee both the freedom of belief as well as the freedom to practice one's religion. The argument could be based on the following evidence, namely, section 15(3) by operation prohibits any religious rule and/or practice, that is in conflict, with of any of the constitutional provisions. On face value and viewed in a particular section 15(3), seems to be redundant as it viewed as a repetition of the supremacy clause $^{34}$, as its purpose seems to be to defend that the legislature will not enact religious law/s that will be contradiction to the constitutional provisions. However, section 15 does not prohibit or affect the constitutional recognition of any religious belief or practice of religious law that is in contradiction to any of the constitutional provisions enshrined in the constitution. Furthermore, section 15(3) is also deemed unnecessary as it does not render any assistance in the protection of freedom of religion, but only, suggests that the legislature may not be stopped by any other law from recognising religious systems or personal law systems. ${ }^{35}$

The result and perhaps the most plausible interpretation relating to section 15 is that the freedom of religious belief coupled with the freedom to practice any law affiliated with such religion or belief, should be assessed as protected in terms of the constitution. This means that all aspects of religious law, such

30 Misra S., 'Sources of Law in Hindu and Muslim Jurisprudence: A Comparative Study,' 10 \& 11 Islamic \& Comp. L.Q 165 (1990-1991).

31 For instance, Isaiah 33:22, states, "that the Lord is our judge, lawgiver and king". See Bible Hub, http://www.biblehub.com, accessed on 20 December 2020.

32 Mofokeng L., 'The Right to Freedom of Religion: An Apparently Misunderstood Aspect of Legal Diversity in South Africa,' 129-130.

33 Constitution of the Republic of South Africa 1996, section 15(1), 15(2) and 15(3).

34 Constitution of the Republic of South Africa 1996, section 2.

35 Mofokeng L., 'The Right to Freedom of Religion: An Apparently Misunderstood Aspect of Legal Diversity in South Africa,' 129-130. 
the law practiced by Muslim's, Hindu's, Judaism, Christianity as well as other personal laws are deemed to form part of the South African legal system, except, where they may be direct conflict with any of the constitutional provisions. Therefore, when deciphering the common law, the judiciary should demonstrate an active role in the interpretation of section 15 to include both the right to freedom of belief as well as the right to practice that belief. It may be mentioned that the attitude of the judiciary in early days of South Africa's democracy were constrained in adopting a liberal interpretation by way of protecting both belief and practice of one's belief according to the principles of the relevant personal laws, to the extent they also ignored those personal law of people, where there was no violation of any of the personal laws that violated the constitutional provisions, especially those contained in the Bill of Rights. However, the judiciary has adopted a liberal approach by protecting both the practice and belief of one's personal laws, in so doing, also altering the existing common law.

\section{CONCLUSION}

The case of Major Fatima Isaacs is indeed a novel issue in South Africa. There is no case law relating to the wearing of a headscarf, however, there is case law dealing with the section 15 of the Republic of South Africa Constitution, which could very well be applied in the circumstances. If the above understanding relating to the freedom of religion in South Africa is sound, then the question, is why, does the judiciary continue on an ad hoc basis to limit the non-recognition and enforcement of religious law. The constitutional interpretation clause situated in the constitution obliges the judiciary 'to promote the values that underlie an open and democratic society based on human dignity, equality and freedom' and to 'promote the spirit, purport and objects of the Bill of Rights. Clearly the courts have come to the realisation of certain inconsistencies in their application of the Bill of Rights pertaining to religious law. However, recently, the judiciary has continuously engaged the issue of religious law and must be congratulated for the recognition of certain aspects of religious laws. This votes well for the judiciary in changing the existing common law, to align itself with the various constitutional provisions, such as the right to equality, the right to human dignity and the right to freedom of religion. Although, it may be postulated that women who choose to be associated with a particular culture or belief system, even if they are unequal to the opposite sex, cannot bring into question the constitutionality of any such rules that form part of such a culture or belief. 
The implication is that women who choose to abide to a religious legal system are subject to the laws of that legal system, regardless of their social position within that system. This perspective would seriously impede the transformation process in all areas of South African society that is founded on equality and human dignity. It is therefore the burden of the state and all its organs placed on it by the constitution to strive to achieve true equality and not only equality on paper. The repercussion of a failure to take positive measures or to act in certain circumstances could very well amount to unfair discrimination. It is therefore argued that equality is a constitutional right available to all (especially women and children, who are most at risk), regardless of whether they adhere to a particular religion or belief system other than the existing South African common law. And finally, both formal and substantive equality are recognised in the South African constitution and the right to human dignity proceeds from the assumption that the dignity of all humans must be respected by virtue of their membership to humanity.

\section{REFERENCES}

BBC.com, http://www.bbc.co.uk, accessed on 20 December 2020.

Bhattacharjee A., Muslim Law and the Constitution, $2^{\text {nd }}$ ed (Calcutta: Eastern Law House, 1994).

Bible Hub, http://www.biblehub.com, accessed on 20 December 2020.

Coertzen P., 'Constitution, Charter and Religions in South Africa,' African Human Rights Law Journal (2014): 127-142.

eNCA, 'SANDF drops charges against hijab-wearing officer,' www.enca.com, accessed on 31 December 2020.

History, 'September 11 Attacks,' http://www.history.com, accessed on 14 July 2020.

Muslim Judicial Council (SA), http://www.mjc.org.za, accessed on 14 July 2020.

Misra S., 'Sources of Law in Hindu and Muslim Jurisprudence: A Comparative Study,' 10 \& 11 Islamic \& Comp. L.Q 165 (1990-1991).

Mofokeng L., 'The Right to Freedom of Religion:AnApparently Misunderstood Aspect of Legal Diversity in South Africa,' Law Democracy and Development, vol. 11/2 (2007): 129-130.

Rautenbach C. (ed.), Introduction to Legal Pluralism in South Africa, $5^{\text {th }}$ ed. (South Africa: LexisNexis, 2018). 
Rautenbach C., 'Muslim Marriages in South Africa,' Griffin's View on International and Comparative Law, vol. 7/1 (2006): 55-74.

Rautenbach C., 'Some Comments on the Current (and Future) Status of Muslim Personal Law in South Africa,' Potchefstroom Electronic Law Journal, vol. 2 (2004): 1-34.

South African Law Reform Commission Project 106 - Islamic Marriages and Related Matters (July 2003).

South African Law Reform Commission Project 59 - Islamic Marriages and Related Matters (May 2000)

Warren C., 'Lifting the Veil: Women and Islamic Law,' Cordoza Journal of Law \& Gender, vol. 15/1 (2008): 33-65.

Yusuf Ali A., The Holy Quran: Text, Translation and Commentary (Lahore: Ashraf Press, 1938).

\section{Statute}

Constitution of the Republic of South Africa 1996. 